\title{
CONSERVATION EDUCATION ON THE ACADEMIC LEVEL IN SOUTHERN AFRICA
}

\section{J DU P BOTHMA}

\author{
Eugène Marais Chair of Wildlife Management \\ University of Pretoria \\ Pretoria \\ 0002
}

\section{Introduction}

Conservation in some form, albeit dormant at times, has probably been with man for many centuries. Yet wildlife conservation as a science is a relatively new concept, which basically originated in the United States of America (USA). That country also led the world in developing conservation education. This lead was followed by most progressive countries, although the nature of conservation and its related educational processes has been adopted to the attitudes and needs of individual countries.

The oldest undergraduate course in wildlife conservation (through management) started in the USA in 1924, and this was followed five years later by two more courses. By 1948 there were 23 colleges offering wildlife management training in the USA (Trippensee 1948) and this increased to 97 in 1970 (Evenden 1971). The first textbook on wildlife conservation, and one still widely used, appeared in 1933 when Leopold published his book: "Game Management" (Trippensee 1948).

The expanding interest in academic education in conservation has recently become the focus for careful re-evaluation in the USA and also in the Republic of South Africa (RSA). However, before discussiong conservation education, one must first consider what is conservation.

\section{Conservation}

Conservation and management of wildlife have become almost synonymous since Leopold (1933) expounded on his principle of conservation through wise use. Different authors give varying views on what they consider to be the essence of conservation. Clarke (1973) said that conservation is religion because the religious impulse is directed primarily to the conservation and promotion of life. Like wildlife conservation, this leads to the riddance of anything considered as hostile and the enhancement of what is thought to be favourable to life. Warren and Goldsmith (1974) see conservation as the meeting point of cultural, 
social and economic systems on the one hand and natural systems at the other and say that conservation actions aim at the planned, harmonious interlocking of these two sets of systems and requires a knowledge of both. Darwin already showed man's place in the panorama of creation, but it remained for Leopold to define man as a geological and ecological force in nature and to hold that man has an inescapable responsibility for the land. Lately the importance of the landscape has been added to man's list of conservation concern (Hickey 1974).

\section{Wildlife}

The conservation actions that we are dealing with in this paper are those associated with wildlife. Originally wildlife was written as two words, but since the early 1930's it is regarded as one word. To the ecologist wildlife simply means all living things (Hickey 1974). Leopold (1933) stated the objective of wildlife conservation to be: to retain for the average citizen the opportunity to see, admire and enjoy, and the challenge to understand the varied forms of wildlife indigenous to his state.

\section{Universities and conservation training in Southern Africa}

Conservation education on the academic level in southern Africa is found at many institutions. The extent and emphasis of this training depends on the aims and interest of the specific university, and are often those of one or more lecturer. It is not the aim of this paper to discuss these various courses or even to attempt to evaluate them. What will be tried, however, is to examine why and how we are training students in wildlife conservation as seen against the background of what happens to these people once they leave the universities.

The major universities involved in wildlife conservation education in southern Africa are: Natal, Pretoria, Rhodesia, Stellenbosch and to a lesser extent now also the Witwatersrand. A broader course in environmental conservation is presented at Cape Town. The graduates produced by these institutions find employment in the whole conservation spectrum in southern Africa, with the universities of Natal, Pretoria and Rhodesia the main suppliers. This crop of conservation-trained biologists has led to the question of whether we are not overstocking a limited market with qualified graduates who may not all find the employment they were specifically trained for and with the resultant frustration of some graduates. This problem, however, is not limited to southern Africa and has recently been discussed in depth in the United States of America. The results of their evaluation of wildlife student training versus available employment can also be applied to southern Africa. Before doing so, however, let us briefly look at some aspects of conservation curricula. 


\section{Conservation curricula}

Conservation training is so broad that the setting up of any one detailed curriculum is as impossible as it is undesirable. However, a wellrounded programme can be viewed as an equilateral triangle of environment, biology and land-use (Trippensee 1948). The basic approach is to develop students qualified to tackle management and research problems on an inter-agency and interdisciplinary basis.

The renewable resources of the world have been so thoroughly altered by man that conservation without management is seldom possible (Warren and Goldsmith 1974). The modern conservation student must therefore, be trained in environmental analysis and control, the characteristics and needs of wildlife and in management techniques (Trippensee 1948). This takes time to acquire and it is usually built on a cornerstone of biological sciences (Larson 1971). The most important point to remember, however, is that the natural environment, although infinitely complex and varied, is a dynamic, organic whole and therefore cannot be properly investigated in isolation (Owen 1975). Furthermore, whatever his training, the benefit of well-planned education is that the student may be successful in a wide spectrum of employment situations (Scott 1975).

\section{Employment opportunities and graduate training}

A student entering a university for conservation training is from three to ten years away from terminal graduation depending on the nature of his research and training. This makes predictions of the employment opportunities that he will face upon completion of his studies impossible, and emphasises that training in any field of science must be more than a route to eventual employment. Education, especially at the graduate level, should aim at more than preparing a student for a narrow professional job; it should aim at producing a better citizen (Scott 1975).

Universities must provide students with a realistic appraisal of the current employment facilities in their chosen field of study. Having done this, no education institution should prohibit or dissuade a suitably qualified student from participating in any study course provided that that institution has the necessary room and manpower to ensure quality instruction to all individuals (Sanderson 1975). This approach eliminates arbitrary enrollment quotas (Hale 1975) and supports the concept of supply and demand in which competition for the available employment positions should benefit the best qualified graduates and in turn enhances the stature of the conservation profession (Peterle 1975). In accepting a student for graduate training we must resist the temptation to accept doubtful students simply to increase class sizes, to meet research obligations or to initiate research that we are urged to undertake. Acceptance of mediocre students is unfair to student and the 
community. This approach should result in enrollment limitations unrelated to employment opportunities (Scott 1975).

The wildlife profession is the mainstream of the environmental movement and a change in some wildlife aspect often signals a "disease" of the environment. Thus wildlife graduates are also well qualified to work in many interdisciplinary environmental studies (Scott 1975). There is also no need for the student qualified in conservation to limit himself to that field of employment. We need knowledgeable citizens in all spheres of life. For example, one suitably trained and motivated high school teacher can probably do more long-term good for conservation than a host of professional wildlife biologists. A wildlife graduate does not necessarily lose the value of his training if he is employed outside the direct conservation sphere (Sanderson 1975).

Training of students must also be advanced to keep pace with new developments in their chosen subject. This cannot be achieved by preventing acceptable candidates from study simply because they are not assured of immediate employment in their major field of study (Scott 1975).

\section{Correct use of available graduates}

Another serious question affecting the training of conservation (wildlife) graduates is: are we using our graduates correctly, even when they secure professional wildlife jobs? I believe not. In most conservation bodies in southern Africa the bulk of the research staff have either completed four years (B.Sc. Honours) or five to six years (M.Sc.) of study. These men are then required to do in depth research which in turn is used to make long-term management proposals. These actions, I believe, should only be entrusted to men with doctoral training. While exceptions do occur, the average student entering employment with a B.Sc (Honours) degree is at best qualified to act as a conservation field officer, reserve manager or technician.

We are making too many conservation and management decisions based on information obtained through research which has barely scratched the surface. One of the most serious problems in this connection is that while most conservation graduates receive interdisciplinary training (the basis of all ecology), they are upon formal employment often required to work in isolation or with the minimum of interand intra-agency co-operation. This results in a waste of time and manpower. Scott (1975) states that if we have learned anything at all from the environmental crisis it is that problems must be resolved through interdisciplinary and interagency co-operation. The conservation graduate of today receives such training but usually can only apply it on a limited scale in his own work and research once he is professionally employed. This matter calls for a serious re-evaluation by conservation agencies on how they are using their available manpower. 
In southern Africa we should strive for increased training as the basis of all levels of conservation employment. Field staff such as law enforcement officers, reserve managers and game rangers are increasingly required to collect wildlife management and research information and must be truly professional in their training. This can only be done by setting a B.Sc. degree in wildlife conservation as a minimum requirement for their training (Sigler 1975).

The law enforcement or nature conservation officer of today is a broadly-based resource manager. His actions must be based on the correct applicable biological and political principles. To convince the layman of the need for conservation the field officer must have the knowledge to do so and the ability to explain his conservation actions.

Field and research staff also too often clash with each other, to the detriment of conservation. According to Sigler (1975) this is partly the result of administrative restrictions involving educational requirements, working hours, social status and salary. It is suggested that field staff be given equal status and opportunities at education and career-building. This is the basis of any conservation action. A field officer who understands the actions of research staff can better evaluate and defend them. The law enforcement officer or game ranger must therefore, have a professional status and attitude of his own. He often not only creates the public image of conservation but he usually is the public image of any conservation body. This requires basic training as a biologist and advanced training in several fields of his own (Sigler 1975), a love for outdoor work and a real interest in wildlife (Trippensee 1948).

Conservation action without reliable factual information usually leads to the deterioration of the situation (Dasmann 1972). Basic conservation research is the field of the Master's candidate, and in depth reserach requires training at the doctoral level (Trippensee 1948). When conservation bodies do not have the staff to carry out research on this basis they should seriously consider using suitable graduates on ad hoc projects involving temporary (project) employment ties only. Research by a Master's degree candidate usually only produces a man who has a good understanding of the research techniques (not principles) in his field of study and practice in writing a finished report (Trippensee 1948).

\section{The woman in conservation}

More and more women are becoming interested in conservation employment. In 1971 in the USA $13 \%$ of all students at the top 20 wildlife schools were women (Rongstad and Hickey 1972). These people can all be used successfully, especially as public relations experts. Women school teachers with conservation training can also be of inestimiable benefit to the whole conservation movement. 


\section{Conservation at the national level}

Successful students in conservation enter a variety of employments at the national level. Let us briefly consider this environment into which they venture and examine their role in it.

Government and semi-government conservation action may often be considered slow and difficult to initiate, but the powers of legislation, taxation and access to funds make it ultimately the most effective (Warren and Goldsmtih 1974) and one which employs most conservation graduates. The important prerequisite for any conservation action or body is a clear statement of demands. It is my belief that we in the RSA need a continuous reassessment of our conservation progress and our use of men trained in conservation matters. This can only be achieved effectively if we have a well-planned comprehensive National Conservation Action Plan to serve as our reference guide. In setting up this plan it will be well to reassess our whole conservation movement and to redefine the tasks of the various conservation bodies in South Africa.

We cannot live in isolation. To pretend that the problems of other nations, and also other conservation bodies, can be ignored, is like telling a fellow passenger that his end of the boat is sinking (Dasmann 1972). One of our most immediately urgent conservation tasks in the RSA is to obtain all the land needed for conservation and then to use it properly. In doing so we must remember that cheap budgets often only lead to cheap results! Once we have secured this land we can start worrying about who shall manage it and how it is to be done.

\section{Conclusion}

It should be clear that there is scope for reassessment of our entire attitude to conservation education, its products and their employment environment. The student with a bachelor's degree does not automatically have a certificate to professional employment and in depth research should only be done by senior students. Field officers constitute the largest single career group in conservation, should become better qualified and should become more involved with research and management programmes.

A broad approach to environmental conservation has become a necessity. This can only be achieved by a National Conservation Action Plan administered on a national level. The guidance and impetus for the implementation of such a national conservation plan should come from top government executive level.

One-sided approaches to conservation usually end in failure. Nobody can escape some share of responsibility; nobody can avoid the world in which he lives. Failure to act can only result in the need to live with the consequences of other people's action (Dasmann 1972). 


\section{REFERENCES}

CLARKE, C H D 1973. Conservation revisited. Wildl. Soc. Bull. 1(2): 106-108.

DASMANN, R F 1972 Environmental Conservation. 3rd Ed. New York: John Wiley and Sons.

EVENDEN, F G 1971. Wildlife student enrollment up 25,4\% over '68. Wildl. Soc. News 132: 1-3.

HALE, J B 1975. Comments on Scott's views on the training of wildlife students. Wildl. Soc. Bull. 3(2): 62-63.

HICKEY, JJ 1974. Some historical phases in wildlife conservation. Wildl. Soc. Bull. 2(4): 164-170.

LARSON, J S 1971. The baccalaureate dilemma. Wildl. Soc. News 132:4.

LEOPOLD, A 1933. Game Management. New York: Charles Scribner's Sons.

OWEN, O S 1975. Natural Resource Conservation. 2nd Ed. New York: Macmillan.

PETERLE, T J 1975. Comments on Scott's views on the training of wildlife students. Wildl. Soc. Bull. 3(2): 64-65.

RONGSTAD, OJ and J J HICKEY. 1972. Survey of qualifications of graduate students enrolled in wildlife programs - Fall of 1971. Wildl. Soc. News 143: 45.

SANDERSON, G C 1975. Comments on Scott's views on the training of wildlife students. Wildl. Soc. Bull. 3(2): 65-67.

SCOTT, T A 1975. The training role of co-operative units. Wildl. Soc. Bull. 3(2): 59-62.

SIGLER, W F 1975. Recommended: B.S. degree for state wildlife law-enforcement officers. Wildl. Soc. Bull. 3(4): 173-175.

TRIPPENSEE, R E 1948. Wildlife Management. Vol. 1. New York: McGraw-Hill.

WARREN, A and F B GOLDSMITH Eds. 1974. Conservation in Practice. London: John Wiley and Sons. 